\title{
The Language of Facebook Comments on Political Articles in Jordan
}

\author{
Yousef F. Bader (Corresponding author) \\ Department of English Language and Literature, Yarmouk University \\ Irbid, Jordan \\ E-mail: yfbader@yu.edu.jo
}

Hala H. Obeidat

Department of English Language and Literature, Yarmouk University

Irbid, Jordan

Received: November 4, 2020 Accepted: December 18, 2020 Published: December 27, 2020 doi:10.5296/ijl.v12i6.18113

URL: https://doi.org/10.5296/ijl.v12i6.18113

\begin{abstract}
The present study aims to investigate the types of impoliteness strategies used by Jordanian Facebookers when commenting on some local political posts. To achieve this goal, one hundred comments were collected from ten political posts in Jordan. The types of impoliteness strategies were analyzed according to super and sub-strategies following the model of Culpeper (1996). The findings showed that most strategies were used by Jordanian Facebookers in political posts, including the following: bald on record, positive impoliteness, negative impoliteness, and sarcasm impoliteness. In addition, due to the religious orientation of most people, Jordanians often use supplications, a new strategy not mentioned in Culpeper (1996). Negative and sarcasm impoliteness are the most frequent super-strategies, while bald on record is the least frequently used super-strategy. Each negative and positive impoliteness has sub-strategies. Positive impoliteness is expressed into disassociating from the other, being disinterested, seeking disagreement, and using taboo words. Using taboo words is the most dominant type in positive impoliteness. Negative impoliteness is expressed into frightening, condescending, putting the other's indebtedness on record, and associating the other with a negative aspect. Associating the other with a negative aspect is the most dominant type in negative impoliteness used by Jordanian Facebookers.
\end{abstract}

Keywords: Impoliteness, Political posts, Facebook, Comments, Jordanian 


\section{Introduction}

People now communicate with their families and friends through social media in a new phase of communication which is the electronic one. It has become the main channel of communication among people all over the world. Smart phones and their applications are nowadays in everyone's hands (Sen 2018:7).

Related to social communication is the politeness theory, a fundamental concept in sociolinguistics first formulated by Brown and Levinson(1987). Thomas (1995) defines politeness as a real desire to be enjoyable to others, or as the primary motivation for an individual's linguistic behavior. On the other hand, impoliteness is defined as any kind of linguistic behavior that is evaluated as intending to threaten the face of the hearer or social identity, or as infringing on the supposed community of norms of suitable practice (Mills 2002: 268).

Culpeper and Kadar (2010:9) argue that politeness and impoliteness as concepts deal with "social dynamics of human interactions" indicating that the terms that are related to politeness are 'respect', 'courtesy' and 'deference', whereas those related to impoliteness are 'rudeness', 'discourtesy', and ' verbal aggression'.

Brown and Levinson (1987) distinguish between types of politeness that involve maintaining threats to positive and negative face. Negative face is "the want of every competent adult member that his actions be unimpeded by others" (p. 62). On the other hand, a positive face is "the want of every member that his wants be desirable to at least some others" (p. 62).

Facebook is a platform of social media that people use to communicate with new people or people that one already knows (Baron 2008: 84). In Jordan, Facebook is widely used as a social media tool. Therefore, people make comments on posts or follow one of the posts and comment on it. One type of posts is the political one. If a political post is shown on Facebook, then a huge number of people try to make comments, a matter that has motivated the researchers to carry out the present study on comments on such political posts.

The politeness theory was first proposed by Brown and Levinson (1987). Politeness is defined as "an appropriate behavior in particular situations in an attempt to achieve and maintain successful social relationships with others" (Lakoff 1972:910).

Brown and Levinson (1987:61) state that all competent adult members of a society have two faces, either negative or positive face. Face as defined by Brown and Levinson is "the public self-image that every member wants to claim for himself." For the same researchers (p. 62), the positive face deals with the positive personality that wishes to be appreciated or approved, or the self-image that is claimed by interactions. On the other hand, the negative face represents the desire of each competent adult member to proceed with his actions without being impeded by others. Still according to Brown and Levinson (1987:94), politeness theory is divided into four super strategies: 


\section{Macrothink}

1) Bald on record strategy:when the speaker does the face threatening act (FTA) with maximum efficiency more than he wants to satisfy hearers. A good example of this is direct imperatives:

Give me the notebook

2) Positive politeness: this strategy is oriented to the addressee's positive face by claiming the positive self-image for himself. In this strategy, the speaker attempts to minimize the threat to the hearer's positive face. This strategy is not only usable for face threatening act, but also to make a kind of social correlation between the speaker and the hearer. Positive politeness includes three board mechanisms, presented below:

a) Claiming common ground: it involves that both speaker $(\mathrm{S})$ and hearer $(\mathrm{H})$ have some set in common and share specific wants (goals and values). There are three ways to make this claim.

1) Speaker (S) can convey that hearer's goal or want is wonderful and interesting to $S$ too.

2) $\mathrm{S}$ may claim group membership, by indicating that both $\mathrm{S}$ and $\mathrm{H}$ belong to a category or group of persons who share the same wants.

3) S may claim that both $\mathrm{S}$ and $\mathrm{H}$ have common perspective without necessarily belonging to a group or membership.

b) Conveying cooperation with the speaker $(\mathrm{S})$ and the hearer $(\mathrm{H})$ : if the speaker and the addressee are cooperative, then it means that they share same goals and serve addressee's positive face.

c) Fulfilling addressee's want for some $X$ reason: this last positive politeness strategy includes speaker deciding to redress addressee's face immediately via fulfilling some of addressee's wants.

3) Negative politeness: the speaker attempts to minimize the threat to the addressee's negative face. This strategy can be done by using some sub-strategies such as: be direct, be pessimistic, and giving defense, and so on.

4) Off record: if a speaker wants to do face threatening act and wants to avoid the responsibility for doing it, he can use off record by providing the hearer to decide how to interpret it through a set of defensible interpretations. The language of this off record utterances is indirect.

Regarding the impoliteness strategy, it was established by Culpeper in 1996.Impoliteness " comes about when: 1) the speaker communicates face attack intentionally, or 2) the hearer perceives and constructs behavior as intentionally face attack, or a combination of (1) and (2)" (Culpeper 2005:38).

Culpeper's model of impoliteness involves five strategies as follows:

1) Bald on record impoliteness; 2) Sarcasm Impoliteness; 3) Positive Impoliteness; 4) Negative Impoliteness; 5) Withhold Impoliteness. 
Also, positive impoliteness includes sub-strategies which are: 1.Ignoring and snubbing the other; 2. Excluding the other from an activity; 3. Disassociating from the other; 4. Being disinterested, unconcerned, or unsympathetic; 5. Using inappropriate identity markers; 6. Using obscure or secretive language; 7. Seeking disagreement; 8. Making the other feels uncomfortable; 9. Using taboo word; 10. Calling the other names.

Negative impoliteness includes five sub-strategies which are: 1. Frighten; 2.Condescend, scorn, or ridicule; 3 . Invade the other's space; 4. Explicitly associate the other with a negative aspect; 5. Put the other's indebtedness on record.

This study aims to analyze some impoliteness strategies used in Facebook comments on political posts based on Culpeper's (1996) model; these strategies will be explained more in the theoretical framework.

\section{Social Media}

Recently, social network sites have become one of the most popular destinations for online traffic (Kushin \& Kitchener, 2009). Social network sites are defined as "web-based services that allow individuals to (1) construct a public or semi-public profile within a bounded system, (2) articulate a list of other users with whom they share a connection, and (3) view and traverse their list of connections and those made by others within the system" (Boyd \& Ellison 2008:1).

The sites of social media such as Snapchat, Bebo, Twitter, Instagram, Facebook, and so on, have attracted millions of users on a daily basis. Every site varies from others in terms of communication tools like photo/ video sharing. Some sites attract people based on common things like shared racial, sexual, religious, or national orientations.

People begin to join on social network sites by creating a profile, and then connect with existing friends for contact through the site. A profile contains a list of identifying information such as birthday, education, religion, hometown, and personal interest. The aims of using these sites vary from one person to another. According to Dwyer (2007), these aims are to: 1) know the latest news in the world; 2) post public testimonials; 3) share photos, activities, and events; 4) present an ideal person; 5) maintain relationships by chatting and sending messages.

Social network sites make possible new ways to think, act, and participate with political events. As cited in Fenton (2011:181), these ways of thinking lead to empower social media, create the autonomy with political intent individuals and promote social change (see also Castells, 2009; Stiegler,2008)

Ellion et al. (2007) claim that one of the most popular sites on SNS is Facebook, which was created in 2004. In 2007, its members surpassed 21 million registered persons achieving 1.6 billion of page views each day (Needham \& Company, 2007). According to Rouse (2009), Facebookis defined as "a popular free social networking website that allows registered users to create profiles, upload photos and videos, send messages and keep in touch with friends, 
family and colleagues."According to the same author, Facebook involves public features such as the following:

1) Groups enable members to share things of interest to interact with each other.

2) Events allow members to advertise an event, and then invite guests to attend this event.

3) Pages offer members the ability to make a public page about a specific topic and promote it.

4) Marketplace allows members to post, read and respond toclassified advertisements to buy or sell items.

5) Technology allows members to see which contacts are online and chat with them.

In a few years, the possibility for individuals to engage in online discussion about political issues has grown rapidly (Kushin \& Kitchener, 2009). Evidence has emerged that indicated an effect of political discussion on Facebook. For example, Facebook was effective as a means to find others with similar political views and to plan 2011 street protests in Egypt (Khamis \& Vaughn (2011), cited in Khamis et al. (2012: 5). Moreover, Dalacoura (2012:68) emphasizes the role of 18 social media, especially Facebook and Twitter, in organizing the Arab revolts in 2011 and linking the protesters to each other and the outside world.

Many studies have been conducted on Facebook contents in many fields of social interest like birthdays, weddings, and offering congratulations or condolences. In addition, the role of Facebook and other social media was remarkable during the so-called "Arab Spring" and other political upheavals in 2011 and the following years (see, for example, studies by Iskander 2011; Goodman 2011; Valenzuela 2014; Mor et al. 2015). Debates on Facebook were also heated during elections in various countries, including the USA Presidential Elections since 2008 (see Williams and Gulati 2008; Robertson et al. 2008; Fernandes et al. 2010; Carlisle and Patton 2013; Pennington et al. 2015; Lin 2017; Apuke and Apollos 2017). Public and politicians' participation in political discourse on Facebook has also been the subject of several studies, including ones on comments on political posts and issues (see Chen and Sali 2010; Clarke and Steekamp 2014; Vraga et al. 2015; Heo et al. 2016; Haenschen 2019). Reactions to Facebook extremist political comments (Almoqbel et al. 2019) and hostile media bias on social media expressed in users' comments (Gearheart et al. 2020) were also the subjects of some recent studies.

\section{Theoretical Framework}

Culpeper (1996: 357-358) defines impoliteness as a situation where a speaker communicates a face-attack or the hearer perceives behavior as intentionally face-attacking. As mentioned earlier, Culpeper classifies impoliteness strategies into five types.

1 Bald on record impoliteness: in this strategy, the FTA is established directly, clearly, and unambiguously. This strategy is not related to the hearer's face.

2 Positive impoliteness: this strategy aims at damaging the positive face of the hearer. 


\section{Macrothink}

International Journal of Linguistics

ISSN 1948-5425

2020, Vol. 12, No. 6

3 Negative impoliteness: this strategy is used to damage the receiver's negative face.

4 Sarcasm impoliteness: politeness strategies are used by the FTA insincerely.

5 Withhold impoliteness: this strategy is followed when the politeness work is absent where it would be expected from the speaker.

Culpeper, at the same time, illustrates a number of sub-categories for both positive and negative impoliteness as follows:

Positive impoliteness includes:

1 Ignoring and snubbing the other: when someone fails to acknowledge the other's presence.

2 Excluding the other from an activity.

3 Disassociating from the other: when someone rejects association or common ground with the other.

4 Being disinterested, unconcerned, or unsympathetic.

5 Using inappropriate identity markers: when the speaker uses title and surname. When a close relationship is used, a nickname, or when a distant relationship is used.

6 Using obscure or secretive language: when the speaker uses a code known to others in the group but not the targeted person.

7 Seeking disagreement: selecting a sensitive topic.

8 Making the other feel uncomfortable: when someone does not avoid silence, jokes, or uses small talk.

9 Using taboo words: swearing or using abusive or profane language.

10 Calling the other names: using derogatory nominations.

Negative impoliteness includes:

1 Frightening: when someone threats others that some detrimental actionto the other will occur.

2 Condescending, scorning, or ridiculing: treating the other in a no serious way, or belittling the other.

3 Invading the other's space (literally) such as asking for or speaking about information of intimacy given the relationship.

4 Explicitly associating the other with a negative aspect.

5 Putting the other's indebtedness on record. 


\section{Mll Macrothink}

International Journal of Linguistics

ISSN 1948-5425

2020, Vol. 12, No. 6

\section{Purpose and Method}

The goal of this study is to investigate the impoliteness strategies used by Facebookers when commenting on political posts and to, linguistically, examine these comments as written by Jordanians.

The population of the study includes the political posts and comments on them on Facebook in Jordan. From this population, a sample of 100 comments was chosen from 10 different political posts to get the impoliteness strategies used by Jordanians.

Data were collected through reading and observation executed by the researchers to get the data. A word document was used to write down those comments and categorize them according to strategies and sub-strategies, following Culpeper (1996). The comments and posts were randomly selected, and they varied from long (10 lines) to short (1 line) comments. All the posts were written in standard Arabic Language, but most comments were written in Jordanian Colloquial Arabic. The political posts were gathered from the following seven pages on Facebook: Roya news, Dr. Omar Razzaz (then (June 2018-October 2020) Prime Minister of Jordan) with two posts, The Jordanian Ministry of Water and Irrigation, Prime Ministry of Jordan with three posts, SahihKhabarak (Correct your news), Khaberni (Tell me), and Wadifati (My Job). The posts are numbered as follows for reference:

1. Dr. Omar Razzaz (1)

2. Khaberni (Tell me)

3. Prime Ministry of Jordan (1)

4. SahihKhabarak (Correct your news)

5. The Jordanian Ministry of Water and Irrigation

6. Prime Ministry of Jordan (2)

7. Roya news

8. Dr. Omar Razzaz (2)

9. $\quad$ Prime Ministry of Jordan (3)

10. Wadifati (My Job)

After collection, data were analyzed qualitatively and quantitatively by categorizing them according to main and sub-strategies following the model of Culpeper (1996). A table was designed to show the five impoliteness strategies and the percentage of each to show the differences between strategies. The researchers then analyzed the data linguistically by observing the comments from different political posts on Facebook.

\section{Findings}

This section includes the findings and the analysis of the data collected in the domain of the impoliteness strategies stated by the taxonomy of Culpeper (1996). As mentioned earlier, the 
strategies include bald on record, positive impoliteness, negative impoliteness, sarcasm impoliteness, and withhold politeness. The section also exposes the most common super-strategies and sub-strategies used by Jordanian Facebookers by analyzing them qualitatively.

Table 1 below presents the percentages of super strategies and sub-strategies used by Jordanian Facebookers in their comments. The data analyzed were 100 comments from 10 political posts in Jordan.

Table 1. Percentages of impoliteness strategies used by Jordanian Facebookers

\begin{tabular}{|c|c|c|c|c|c|}
\hline \multicolumn{6}{|c|}{ Types of Impoliteness Strategies } \\
\hline No & $\begin{array}{l}\text { Super } \\
\text { Strategies }\end{array}$ & Sub-strategies & $\begin{array}{l}\text { Number of } \\
\text { findings }\end{array}$ & Total & $\begin{array}{l}\text { Percentage } \\
(\%)\end{array}$ \\
\hline 1 & Bald on record & & 3 & 3 & $3 \%$ \\
\hline \multirow[t]{4}{*}{2} & \multirow{4}{*}{$\begin{array}{l}\text { Positive } \\
\text { impoliteness }\end{array}$} & Disassociating & 4 & \multirow[t]{4}{*}{17} & $17 \%$ \\
\hline & & Being disinterested & 4 & & $4 \%$ \\
\hline & & Seeking disagreement & 1 & & $1 \%$ \\
\hline & & Using taboo word & 8 & & $8 \%$ \\
\hline \multirow[t]{5}{*}{3} & \multirow{5}{*}{$\begin{array}{l}\text { Negative } \\
\text { impoliteness }\end{array}$} & Frightening & 8 & \multirow[t]{5}{*}{56} & $56 \%$ \\
\hline & & Condescending & 13 & & $13 \%$ \\
\hline & & $\begin{array}{l}\text { associating the otherwith a } \\
\text { negative aspectexplicitly }\end{array}$ & 26 & & $26 \%$ \\
\hline & & $\begin{array}{lr}\text { Putting } & \text { the } \\
\text { other'sindebtedness } & \text { on } \\
\text { record } & \end{array}$ & 1 & & $1 \%$ \\
\hline & & Supplication & 8 & & $8 \%$ \\
\hline 4 & $\begin{array}{l}\text { Sarcasm } \\
\text { impoliteness }\end{array}$ & & 24 & 24 & $24 \%$ \\
\hline 5 & $\begin{array}{l}\text { Withhold } \\
\text { politeness }\end{array}$ & & 0 & 0 & 0 \\
\hline & Total & & & 100 & \\
\hline & Percentage & & & & 100 \\
\hline
\end{tabular}

Table 1shows that not all impoliteness strategies are used. Withhold politeness is not used by Jordanian commenters on political posts on Facebook. In fact, only four out of five super strategies are used by Jordanians on Facebook to comment on political posts: bold on record, positive impoliteness, negative impoliteness, and sarcasm impoliteness. The results also show that negative impoliteness is the most frequent super strategy used on Facebook by Jordanians and occurs (56) times or 56\%. Sarcasm impoliteness is the second most frequently used with (24) frequencies or (24\%). Positive impoliteness is the third super strategy used by Jordanian Facebookers and has (17\%). Bald on record is the least used strategy and represents only $(3 \%)$ of the strategies. 
As a result, both positive and negative strategies are achieved in some ways. Positive impoliteness is expressed in four sub-strategies, namely, disassociating from the other, being disinterested, seeking disagreement, and using taboo words. The most frequent type is using taboo words with (8\%). Being disinterested and disassociating from the other are the second most frequent and represent (4\%) each. Seeking disagreement is the least frequent as it represents only (1\%). On the other hand, negative impoliteness strategy is expressed in four sub-strategies, namely, frightening, condescending, associating the other with a negative aspect explicitly, and putting the other's indebtedness on record. The most frequent $(26 \%)$ is associating the other with a negative aspect explicitly, followed by condescending, scorning, or ridiculing $(13 \%)$, frightening $(8 \%)$, and putting on record $(1 \%)$. In what follows, the different super and sub strategies are discussed with examples.

\subsection{Bald on Record}

This is the first strategy stated by Culpeper that is performed by the speaker to attack the hearer's face or to express the opinion in a direct, obvious, concise, and unambiguous way. This strategy represents only (3\%) of the impoliteness strategies used by Jordanian Facebookers in political posts. The following are examples of using bald-on record.

Example (1) from post (4):

عشان تعبي الجيبة: The comment in Arabic

English translation: in order to fill up your pocket.

Transliteration:؟afaan $\mathrm{t}$ ?abbiildzeebih

The commenter directly accused the then Jordanian Minister of Information (JumanaGhunimant) of trying to steal money. The commenter (DuniaGhabrah) expressed anger in a clear and direct way by making this bald-on record accusation against a government minister.

Example (2) from post (4):

طبعا مهورحلة نقاهه و استجمام ونهب سنحه بس:The comment in Arabic

English translation: of course, it was a journey of convalescence, recreation, and stealing. Damn you!

Transliteration:Tab؟an mahuriHlitnaqaahahwistidzmaamwanahbsanHuh bass.

This comment further shows that the commenter also accused JumanaGhunimant that her trip to London was to relax and steal rather than to seek investments. Therefore, this statement, made by a different person,was meant to confirm the accusation in the comment in example (1) and attacked her directly with a negative aspect.

Example (3) from post (8):

خربتوا البلد:Comment Arabic

English translation: you have ruined the country. 
Transliteration:xarrabtuu ilbalad.

The author of this comment blatantly criticized the then Jordanian Prime Minister (Dr.Omar Razzaz) by accusing him of destroying the country and attacking the addressee's face without reservation.

\subsection{Positive Impoliteness}

As mentioned in the introduction, this is one of the impoliteness strategies that is intended to attack the addressee's positive face. There are four sub-strategies of positive impoliteness found in comments on political posts in Jordan. These sub-strategies are in the form of disassociating from the other, being disinterested, seeking disagreement, and using taboo words. Seventeen comments use positive impoliteness in different political posts. Some of these comments are discussed in the following subsections.

\subsubsection{Disassociating From the Other}

Three examples of this type are discussed below. In (4), Sarayreh objected to the decision of the Jordanian Customs Department to launch a platform to organize electronic commerce. In order to stress his rejection of the decision and defy the Customs Department, he suggested a number of measures people who take to counter and foil the Customes' decision. In the other two examples, the commenters made strong statements to attack a person or a procedure.Rababah, in example (5), attacked Dr. Omar Razzaz by asking him to resign from his position as prime minister of Jordan. The commenter, in example (6), objected to the fact that a student got an average of $100 \%$ in the Secondary School Certificate Exams (Tawjihi) by doubting this GPA, as many other Jordanians did. One must notice in example (6) the use of an English phrase "too much", probably meant to attract readers' attention to the extremely high GPA.

Example (4) from post (3):

Comment in Arabic: إذاً لن نشتري ولن ندفع الرسوم وساقوم بتسليم البطاقه للبنك ... وان شاء الله و لابتحصلو ا شلن البطن من المو اطن.... و علامها البسطات...

English translation: So, we are not going to buy, nor will we pay the fees. I will hand over the visa card to the bank... God willing, you will not get one dime from the citizens... is there anything wrong with peddlers?...

Transliteration: ?¡aanlannaftariiwalannadfa?arrusuumwas?aquumbitasliimalbiTaaqahlilbank. .. wa ?in Jaa? allahwalaabitHaSluufiln min almwaaTin... wa?alaamhaalbasTaat...

Example (5) from post (1):

Comment inArabic: استحي عحالك واستقيل

English translation: Have some shame and resign.

Transliteration: ?istaHii؟aHaalakwistaqiil

Example (6) from post (8): 


\section{Macrothink}

Comment in Arabic:!! بس 100\% دو 10ناب

مش كإنه شوي

English translation: Only 100\% your Excellency?!! It may be too much.

Transliteration: bass $100 \%$ dooltak!!? mifka?inuhfwaytuumach??

This finding agrees with Jucker(2009:181) who maintains that disassociating represents a strong criticism of a decision or a person.

\subsubsection{Being Disinterested, Unsympathetic, or Unconcerned}

This strategy constitutes (4\%) of total comments. The following examples illustrate it:

Example (7) from post (5):

هو حدا معو يضحي لا اقطعوها معناش ندفع.:Comment in Arabic

English translation: Is there anyone who has (money) to sacrifice? So, cut it out, because we can't pay.

Transliteration:huuHadaa ma?uuydaHHiilaaiqTa?uuha ma?naafnidfa?.

This commenter was not happy or sympathetic with the decision of the Minister of Water and Irrigation (Raed Abu Al-Saud)not to shut water off during Eid Al-Adha holidays (during which Muslims sacrifice a sheep, cow, or camel). He requested the Minister to cut water off because he could not pay for it.

Example (8) from post (2):

ان شاء الله يكثرن:Comment inArabic

English translation: God willing, they will be more.

Transliteration:?infaa? allahyk $\theta$ arin.

In the second comment, the commenter didn't sympathize with the increase of Jordanian indebtedness; instead he asked God (supplication) to increase the national public debt.

Example (9) from post (2):

ليش تعلمونا سدوا دينكم بعيد عنا :Comment in Arabic

Comment inthe English Language: why are you making us know? Pay your debts without us.

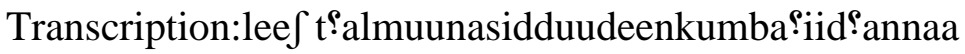

In the third comment, the commenter wasn't concerned or sympathetic, requesting the government to pay the debt without telling the people. Therefore, he was disinterested with the government's problem regarding its debts. 


\section{Mll Macrothink}

\subsubsection{Seeking Disagreement}

Disagreeing with something or somebody is another sub-strategy of positive impoliteness, but it represented only (1\%) of all data sets. Bousfield (2008: 85) emphasizes that this strategy is used to talk about a "sensitive topic or just disagree outright". The following example illustrates this type:

Example (10) from post (6):

Comment in Arabic: لو استثمرتو هم في تطوير مصارف المياه لكان احسن... حسب توقعات علماء الطقس الامطار الموسم القادم اضعاف ما شهرنا هذا العام...

English translation: if (only) you had invested them in the development of water drains, it would have been better... According to weather forecasts, rainfall next season will be double what we had this year...

Transliteration:law ?istaOmartuuhumfiitaTwiirmaSaarifalmiyaahlakaan ?aHsan... Hasabtawaqu?aat?ulamaa?aTTaqsal?amTaaralmauusimalqaadim ?ad?aafmaafahidnaahaðaa al؟aam...

The commenter in this example expressed his disagreement with what was posted on Facebook by the Prime Ministry of Jordan about funds from the Greater Amman Municipality to support Downtown merchants whose goods were flooded and heavily damaged in February 2019. He suggested to invest this money in the development of drainages instead of distributing it to merchants. Then, he gave evidence tosupport his opinion from warnings about even more severe floodings due to extreme weather expected the following year.

\subsubsection{Using Taboo Words}

Based on the research findings, this strategy of positive impoliteness strategy represents (8\%) of total data under study. The following examples and other examples not discussed here due to space limitations show that Jordanian Facebookers use some taboo or cutting words when they criticize someone and express their opinions.

Example (11) from post (5):

Comment in Arabic(FadiAzzam):ابشرك يا وزير المياه الناس مقطو عه عندها المي يعني طقعولك.

English translation: I proclaim it to you, Minister of Water and Irrigation, people don't have water, which means they ignored you (lit., they made weird noises).

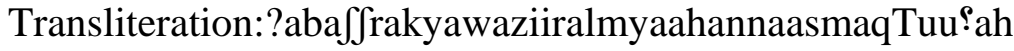

؟indhaaalmayyya?niiTaqqa?uulak.

This commenter criticized the Jordanian Minister of Water and Irrigation for his post about not shutting off water during the Eid Al-Adha holiday by using the taboo word (Taqqa?uulak) which basically means they ignored you.

Example (12) from post (10): 


\section{Al Macrothink}

هو باله تسكر ثمك:Comment Arabic

English translation: For God's sake, shut your mouth.

Transcription:huuballahtsakkirOummak.

This commenter inappropriately requested the then Jordanian Minister of Transport, Eng. AnmarKhasawneh, to stop talking by using the strong word (taboo in the Jordanian society when addressed to higher people) "shut your mouth".

Example (13) from post (8):

متى ودك تروح وتحل عنا، منى تلحق قريك الملقي... لن : Comment in Arabic (Adnan Al-Mawajdeh) نذكركم بخير .. طاري الثيطان و لاطاريكم

English translation: When do you want to go and leave us alone?... When will you follow "your relative Al-Mulqi" (preceding Prime Minister)? ... We will not remember you (plural) for any good...We prefer to speak of the devil the devil instead of speaking of you.

Transliteration:mataawiddaktruuHwitHil؟annaa, mataatilHaqqariibakalmulqii... lannaðkurakumbixayr..TaryafsiiTaanwalaaTaarykum

The commenter wrote this negative comment about the then Jordanian Prime Minister (Dr.OmarRazzaz), stating mentioning his and his predecesor Al-Mulqi's names is worse than mentioning the devil's name. The Devil is known in the monotheistic religions and some other cultures as a cursed evil person who disobeyed God and thus fell in disgrace.

\subsection{Negative Impoliteness}

As mentioned earlier, this strategy is used for damaging the hearer's negative face. In the following subsections, each sub-strategy of negative impoliteness as shown above is discussed with some comments that are selected from the 56 comments including this strategy.

\subsubsection{Warn/Threaten}

The analysis of comments yields that Jordanian Facebookers use this strategy for threatening or frightening the other by affirming that some detrimental actions will occur. This strategy has $8 \%$ of total data as can be seen in some examples below.

Example (14) from post (3):

Comment in Arabic: زيادة الضر ائب لن يؤدي إلا لمزيد من

الركود الاقتصادي آن الأوان ان تجد الحكومه بديل عن الضريبه

English translation: taxes increase will only lead to more economic stagnation; it's time for the government to find an alternative to taxes.

Transliteration:zyaadataddaraa?iblanyu?addii ?illaalimaziid

$\min$ arrukuudal?iqtiSaadii ?aanal?awan ?an tadzidalHukuumahbadiil?an addariibih. 


\section{Macrothink}

International Journal of Linguistics

ISSN 1948-5425

2020, Vol. 12, No. 6

In this example, the author warned the government that the tax increase will lead to more economic stagnation (if the Jordan Customs Department activates the decision to implement electronic commerce).

Example (15) from post (3):

خطوه اخرى للقضاء على الاقتصاد الاردني:Comment in Arabic

English translation: another step to finish off the Jordanian economy

Transliteration:xuTwah ?uxraalilqadaa??alaaal?iqtiSaadal?urdunii.

In this example, the commenter warned the government that the launch of the electronic commerce platform will destroy the economy.

Example (16) from post (2):

ولسه الحبل ع الجرار لا اخر السنه ولا السنه الي بعدها بتزيد او رح تزيد وتزيد طول ما :Comment in Arabic النهج نفسه

English translation: More is still to come! it's going to continue to increase and increase more to the end of the year and evenin the next one and so on, as long as it is the same policy.

Transliteration:

walissahilHabl?aldzaraarlaa ?axirassanihwassanihiliiba?dahabitziid ?auuraHtziid w tziidTuulmaaannahdznafsuh

In this comment, the writer strongly warned that Jordanian indebtedness will be increasing for an unspecified time to come.

The impoliteness of these examples is shown in that the threat denotes both sides of face as the writer warns the other, instilling a belief that his or her action will prove its damage in the end (Culpeper 1996:356). The writer also shows a strong criticism of the government's past behaviors and potential future decisions, which reinforces the harm to face (Jucker2009:175).

\subsubsection{Condescend, Scorn, or Ridicule}

This sub-strategy is not as common as that of associating with a negative aspect explicitly (see section below) and represents $13 \%$ of total data. Some Jordanian Facebookers tend to belittle the other by using proverbs or groups of words, such as when the commenter, in example (17) below, used the Jordanian well-known saying that when "someone is doing his job, it is not a great achievement". The commenter also, in example (18), used an Egyptian proverb to refer to someone who brings worthless things despite serious efforts to make the best of him. On the other hand, the commenter, in example (19), used a phrase to scorn, or ridicule the government.

Example (17) from post (4):

Comment in Arabic:.انجاز.عظي. زغردي الها ياهلاله 


\section{IIMacrothink}

International Journal of Linguistics

ISSN 1948-5425

2020, Vol. 12, No. 6

English translation: great achievement. Make a ululation (expression of great joy), Hilalah (typical Jordanian feminine name); it means that if someone is doing his job it is not a great achievement.

Transliteration:?indzaaz. ؟að’iim. zayridii ?ilhaayahilaalih.

Example (18) from post (6):

Comment in Arabic: ياما جاب الغراب لأمه

English translation: What did the crow bring to its mother? (Egyptian Proverb which means that someone brings worthless things in spite of the efforts that the mother made to bring him up).

Transliteration:yaamaadzaab al-yuraabla?ummuh.

Example (19) from post (3):

Comment in Arabic: ماثين عكس العالم، استمروا.

English translation: you are going against the whole world, keep on going.

Transliteration:maafiin?aks al؟aalam, ?istamirruu.

These examples emphasize that scorn is accompanied by contempt by not seriously reading the other, as in example (19), or by belittling the other, as in examples (17) and (18)(Culpeper :1996:358).

\subsubsection{Put the Other's Indebtedness on Record}

There was only one case where the participant appeared to put the other's indebtedness on record. He adopted his negative criticism from an old sentence which is always said in most political speeches, as presented in the following example:

Example (20)from post (7):

Comment in Arabic: الانسسسسسان اغلى ما نملك سو اليف قديمه وكذب بسلامه بسلامه بسلامه شكر ا حموده.

English translation:"the human being is the most precious thing we have"; that is an old saying and a lie. Bye, bye, bye and thanks Hamoudah.

Transliteration:al?insaan ?aylamaanamliksawaaliifqadiimihwakiðbbissalaamihbissalaamihbis salaamihshukranHamuudh

The commenter means that this saying, which was first stated by the late King Hussein of Jordan, has been repeated so often by less caring politicians that it has lost its original seriousness and truth.

\subsubsection{Explicitly Associate the Other With a Negative Aspect}

Culpeper (1996:358) categorizes this strategy as an attack of the interlocutor's negative face. It is often used by Jordanian Facebookers and appears in $26 \%$ of the total data. It is shown in 
the examples below that these expressions are used in a negative way by using explicitly associate the other with a negative aspect.

Example (21) from post (1):

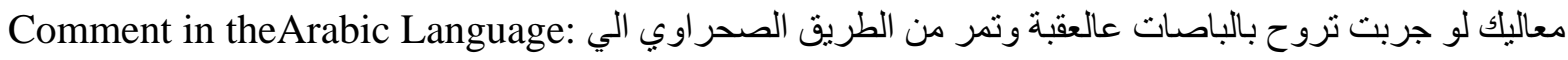

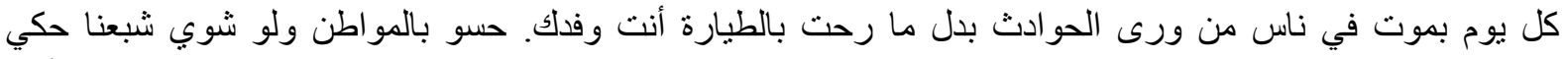

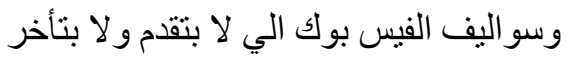

English translation: (I wish) you tried, your Excellency,to go to Aqaba by bus through the Desert Road where car accidents take place and people die every day instead of going with your delegation by plane.Think only a little about your citizens, because we are fed up with the talk and stories of the Facebook posts that have been making no progress whatsoever.

Transliteration:ma?aliik law dzarrabittruuHbilbaaSaat?al؟aqabahwitmurr min aTTariiqaSSaHrawiiilliikulyoombimuutfiinaas

$\min$ waraaalHawadi $\theta$ badalmaaruHtbiTTiyaarah?antawwafdak.

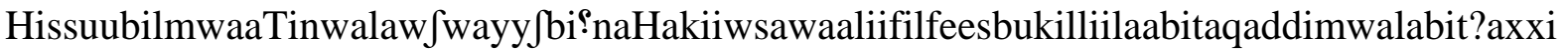
r.

In this example, the writer strong criticized Dr. Omar Razzaz for going from Amman to Aqaba (310 kms. to the south) by plane rather than by bus or car which common people use. He thought the then Prime Minister of Jordan should have shown some sympathy with the common populace.

Example (22) from post (2):

سبب ارتفاع الدين العام.... السرقات والفساد يتم تصدير هذه الأمو ال للخارج. :Comment in Arabic

English translation: The reason behind the high rate of the general debt is related to thefts and corruption; money is being exported outside the country.

Transliteration: sabab ?irtifaa?addeen al?aam assariqaatwilfasaadyatimtaSdiirhaðihial?amwaallilxaaridz

The commenter, in this example, also applied this strategy by stating the reasons for the increase of indebtedness such as "thefts and corruption".

Example (23) from post (4):

Comment in Arabic: استثمار ات شو مهي نص المستثمرين راحو على تركيا ومصر من كثر الضر ائب

English translation: what investments are you talking about? Half of the investors went to Turkey and Egypt because of the many taxes.

Transliteration:?istiOmaraatfuumahinuSSalmustaOmiriinrahuu?alaaturkiaawamaSr min kuӨraldaraa?ib

Additionally in this example, AlaaAlyan confronted the Minister of Information with the fact that half the investors left Jordan to Egypt and Turkey because they could not afford paying the many taxes imposed on them. 


\section{MlMacrothink}

\subsubsection{Supplication}

There is another sub-strategy of negative impoliteness strategy presented in this study which does not belong to any of the classifications established by Culpeper's (1996). This strategy is examined under the negative impoliteness strategy because Jordanian Facebookers use negative supplications to comment on political posts. Some examples of invocations can be seen in the examples below.

Example (24) from post (9):

Comment in Arabic: البين يطسك مصدق حالك مراسل في البلديه بمون احسن منك لو بتستحي بحكي روح نام احنilلك.

English translation: May you be plagued with death. Do you really believe yourself? An office boy in the municipality is more influential than you are. If you have some shame, go to sleep because it is better for you.

Transliteration:ilbeenyTussakmSaddiqHaalakmuraasilfiilbaladiyyihbimuun ?aHsanminnak law bitstaHiibaHkiiruuHnaam ?aHsanlak.

In this comment, the author insulted the Jordanian Prime Minister by calling a curse upon him through the Karaki (Jordanian southern city) term (ilbeenyTussak) which means "I wish some calamity occurred to you" (supplication for something bad). He also tried to belittle the Prime Minister by saying that an office boy in a small municipality has more power than him.

Example (25) from post (10):

الله يسخطكو بس:Comment in Arabic

English translation: May Allah make a calamity fall on you.

Transliteration:allahyisxaTkuu bass.

The commenter objected to an utterance of the Jordanian Minister of Transport by invoking upon him the negative supplication stated in the example, which is usually made for enemies or evil persons.

Example (26) from post (1):

Comment in Arabic: روح يا شيخ منك له الهه لا يسامحك

English translation: Go away, Sheikh; Allah will take care of you; may He never forgive you.

Transliteration:ruuhyafeexminnaklalaahallahlaaysaamHak.

The commenter also used negative impoliteness to attack the the Jordanian Prime Minister by invoking on him the supplication "MayAllah never forgive you". The reason why he called him 'sheikh" is not clear but it may been have used to refer to the Prime Minister as the head of a tribe rather than the head of a government, which further illustrates his disdain of Razzazz. 


\section{$\Lambda$ Macrothink}

\subsection{Sarcasm}

This strategy is another type of impoliteness strategies found by Culpeper's (1996). Sarcasm or mock politeness, as mentioned before, is performing the face threatening act with politeness strategies that are clearly insincere to the addressee's face. This strategy in the study constitutes $(24 \%)$ of total data. Examples of sarcasm can be seen in the following comments.

Example (27) from post (2):

Comment in Arabic: عفيه النشامى

English translation: Good job, Champions.

Transliteration:@afiyyihinnfaama

The commenter in this example apparently lauded but actually sarcastically mocked the Jordanian government for increasing Jordanian indebtedness.

Example (28) from post (1):

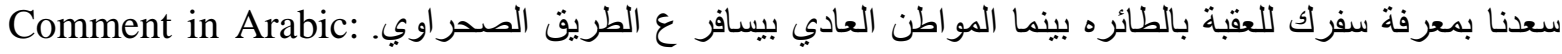
سررنا بمعرفة انه ما في فرق بين مو اطن ومسؤول فيكي يا بلدي.

English translation: we were delighted to learn that you traveled by plane to Aqaba while the normal citizen travels through the Desert Road. We were also delighted to know that there's no difference between a citizen and an official in you, my country.

Transliteration:su؟idnabima?rifatsafaraklil؟aqabahbiTTiyyarahbaynamaaalmawaaTin al؟aadiibysaafir?aTTariiqaSSaHrawii. surirnabima?rifat ?innuhmaafiifarq been muwaaTinwamas?uulfiikiyabaladii.

The writer, in the comment above, used the style of mockery to criticize Dr. Omar Razzaz for going to Aqaba by plane instead of using the desert road which common people use. Sarcastically stated, the travel by plane shows that there is no difference between ordinary citizens and government officials.

Example (29) from post (3):

Comment in Arabic: بااخي و الله لازم تحطو ا ضريبة بدل استهلاك هو ا... على كل واحد بتنفس في الأردن... هيك اعنى ممكن تزبط معكو ا.. بس عاد البير قاعه مكسور... مش راح بـ يمتلي..

English translation: Hey, brother, you must add a tax on air consumption by each breathing person in Jordan...by this way, you might be able to make up (for your budget expenditures).... But the bottom of the well is broken (leaky)...so it will never be filled.

Transliteration:yaaxiiwallahlaazimtHuTTuudariibihbadal

?istihlaakhawa...

؟alaakulwaaHidbitnaffasfiil?urdan... heekmumkintuzbuT ma?kuu.. bass?aadilbiirqaa?uh maksuur.. mifraHyimtalii.. 
In this comment, the writer sarcastically called to add a tax for air consumption in order to fill up the government's treasury; then, he regrets, also sarcastically, the fact the treasury is always leaking, so it will never fill up. He here uses a well-known Jordanian saying: the floor of the well is broken/cracked to compare the treasury to always leaky water well.

\section{Discussion and Summary}

The study found that impoliteness strategies are widely used by Jordanians to comment on political posts on Facebook. It was also found that Jordanian people use different strategies to comment on such posts and that this difference is due to the nature of the political post itself. The strategies used include positive impoliteness, negative impoliteness, bald on record, and sarcasm impoliteness, also found in different research areas (see Zhong, 2018; Rosanti, 2016; Primadianti, 2015; Chintiabela, 2017; Gunawan, 2017; Dhorifah, 2016; Shofyah, 2015; Hammod and Abdul-Rassul, 2017; Shinta et al. 2018). All of these studies discussed examples of four of the five strategies found in this study except for Shofyah who found all five strategies of the impoliteness theory.

The study is deemed to be the first to investigate Facebook comments on political articles in Jordan by applying Culpeper's (1996) Impoliteness strategies, and it is the only one where negative impoliteness is used more than positive impoliteness. In most of the studies mentioned, positive impoliteness is the most frequent, and this agrees with results by Zhong (2018), Rosanti (2016), Chintiabela (2017), Gunawan, (2017), and Shofyah (2015), Shinta et al. (2018) who addressed the important influence of gender in social media, and Hammod and Abdul-Rassul (2017) who compared between English and Arabic Facebook comments.

Bald on record impoliteness is rarely used by Jordanian Facebookers and this differs from findings in other studies. According to Hammod and Abdul-Rassul (2017), both bald and sarcasm impoliteness are used in Arabic Facebook comments with similar frequencies. In English Facebook comments sarcasm impoliteness is the least frequent, contrary to findings in the present study where sarcasm is widely used.

Regarding the sub-strategies of negative and positive impoliteness, Jordanian Facebookers use disassociating from the other, being disinterested, seeking disagreement, and using taboo words in positive impoliteness. They also use frightening, condescending, putting the other's indebtedness on record, and associating the other with a negative aspect in negative impoliteness. Other studies used other strategies, which differ in one way or another from those in the present study.

\section{Conclusions and Recommendations}

Based on the study findings, the following conclusions can be made:

1- The study has revealed a new strategy used by Jordanians; it is negative supplication which does not belong to any classification established by Culpeper's (1996). Using supplications or invocations reflect the religious and Islamic influence on Jordanians. 


\section{Al Macrothink}

International Journal of Linguistics

ISSN 1948-5425 2020, Vol. 12, No. 6

2- The findings of this study reveal that most Jordanians comment on political posts by using negative impoliteness. This reflects Jordanians' general negative attitudes toward their government's policies, especially regarding economic issues.

3- It is found that Jordanians do not use withhold politeness on Facebook because Facebook does not deal with facial expressions.

4- The findings of this study also show that some sub-strategies of the positive impoliteness are not used by Jordanian Facebookers such as ignoring and snubbing the other, excluding the other from an activity, using inappropriate identity markers, using obscure or secretive language, calling the other names. Only one sub-strategy of the negative impoliteness, invading the other's space, is not used. This may be due to the conservative nature of most Jordanians who generally avoid directly offending the other.

It is anticipated that the study's findings can present useful input to researchers who want to carry studies similar to this one. In the light of the study's results, the researchers suggest certain topics which can be examined in the future such as the following:

1- It might be useful if further studies examine the comments on political posts on Facebook within the politeness theory.

2- A similar study can be conducted taking into account the effect of gender.

3- The study did not consider the emotional faces used in Facebook; therefore, it is recommended to handle this topic in future studies.

4- The study handled the impoliteness strategies in Jordanian Arabic; future research to study the same topic in other Arab countries is suggested.

\section{Phonetic Symbols of Arabic Sounds}

\subsection{Consonants}

\section{Arabic Consonants Symbol Description}

\begin{tabular}{|c|c|c|}
\hline$\varepsilon$ & $?$ & Glottal stop \\
\hline ب & $\mathrm{b}$ & Voiced bilabial stop \\
\hline$ت$ & $\mathrm{t}$ & Voiceless dento-alveolar stop \\
\hline$\dot{H}$ & è & Voiceless inter-dental fricative \\
\hline ج & d3 & Voiced post-alveolar affricate \\
\hline$\tau$ & $\mathrm{H}$ & Voiceless pharyngeal fricative \\
\hline$\dot{\tau}$ & $\mathrm{x}$ & Voiceless uvular fricative \\
\hline$د$ & $\mathrm{~d}$ & Voiced dento-alveolar stop \\
\hline$\dot{j}$ & ð & Voiced alveolar fricative \\
\hline J & $\mathrm{r}$ & Voiced alveo-palatal trill \\
\hline j & $\mathrm{z}$ & Voiced alveolar fricative \\
\hline س & $\mathrm{s}$ & Voiceless alveolar fricative \\
\hline ش & s & Voiceless alveo-palatal fricative \\
\hline
\end{tabular}




\begin{tabular}{|c|c|c|}
\hline 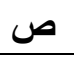 & $\mathrm{S}$ & Voiceless alveolar emphatic fricative \\
\hline 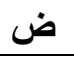 & $\mathrm{d}$ & Voiced alveolar emphatic stop \\
\hline b & $\mathrm{T}$ & Voiceless dento-alveolar emphatic stop \\
\hline ظ & $\partial^{\varsigma}$ & Voiced alveolar emphatic fricative \\
\hline$\varepsilon$ & 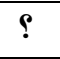 & Voiced pharyngeal fricative \\
\hline$\dot{\varepsilon}$ & 8 & Voiced uvular fricative \\
\hline ف & $\mathrm{f}$ & Voiceless labio-dental fricative \\
\hline ق & $\mathrm{q}$ & Voiceless uvular stop \\
\hline ك & $\mathrm{k}$ & Voiceless velar stop \\
\hline J & 1 & Voiced alveolar lateral \\
\hline s & $\mathrm{m}$ & Voiced bilabial nasal \\
\hline ن & $\mathrm{n}$ & Voiced alveolar nasal \\
\hline هـ & $\mathrm{h}$ & Voiceless glottal fricative \\
\hline و & $\mathrm{w}$ & Voiced labio-velar glide \\
\hline ي & $\mathrm{y}$ & Voiced palatal glide \\
\hline
\end{tabular}

\subsection{Vowels}

A) Short vowels

\begin{tabular}{lll}
\hline فتحة & a & Front, nearly half-open, low unrounded \\
\hline ضمة & u & Back, nearly close, high rounded \\
\hline كسرة & i & Front, open, high unrounded \\
\hline
\end{tabular}

B) Long Vowels in Jordanian Collequial Arabic

Long vowels are doubled by short ones. They are as follows:

aa, uu, ee, oo, and ii

\section{References}

Almoqbel, M. Y., Wohn, D. Y., Hayes, R. A., \& Cha, M. Y. (2019). Understanding Facebook news post comment reading and reacting behavior through political extremism and cultural orientation. Computers in Human Behavior, 100, 118-126.

Apuke, O. D., \&Apollos, I. N. (2017). Public perception of the role of Facebook usage in political campaigns in Nigeria. Informing Science: International Journal of Community Development \& Management Studies, 1, 85-102.

Bousfield, D. (2008). Impoliteness in interaction. Amsterdam: John Benjamins Publishing Company.

Boyd, D. M., \& Ellison, N. B. (2008). Social network sites: definition, history, and scholarship. Journal of Computer-Mediated Communication, 13(1), 210-230.

Brown, P., \& Levinson, S, C. (1987). Politeness: some universals language usage. Cambridge University Press. 


\section{Al Macrothink}

International Journal of Linguistics

ISSN 1948-5425

2020, Vol. 12, No. 6

Carlisle, J. E., \& Patton, R. C. (2013). Is social media changing how we understand political engagement? An analysis of Facebook and the2008 presidential election. Political Research Quarterly, 66(4), 883-895.

Castells, M. (2009). The mobile communication society. Report, Los Angeles: Southern California University.

Chen, H., \&Sali, M. (2010). A Qualitative study of Iranian Facebook users perceptions of using Facebook in Iran's E-participations activities. Master's thesis, Swedish Business School - Informatics, Örebro University. Retrieved from http://www.diva-portal.org/smash/get/diva2:372479/FULLTEXT01.pdf

Chintiabela, G. (2017). A pragmatic analysis of impoliteness strategies in carrie movie. SastraInggris-Quill, 6(1), 79-86.

Cruse, A. (2006). A glossary of semantics and pragmatics. Edinburgh: Edinburgh University Press Ltd.

Culpeper, J. (1996). Towards an anatomy of impoliteness. Journalof Pragmatics, 25, 349-367.

Culpeper, J. (2005). Impoliteness and entertainment in the television quiz show: the weakest link. Journal of Politeness Research, Language,Behaviour, Culture, 1(1), 35-72.

Culpeper, J., \& Kadar, D. Z. (2010). Historical (Im) politeness. Zurich: Peter Lang.

Dalacoura, K. (2012). The 2011 uprisings in the Arab middle east: political change and geopolitical implications. International Affairs, 88(1), 63-79.

Dhorifah. (2016). An analysis of impoliteness strategies in boyhood movie transcript. Jakarta: SyarifHidayatullah State Islamic University.

Dwyer, C., Hiltz, S., \& Passerini, K. (2007). Trust and privacy concern within social networking sites: A comparison of Facebook and MySpace. AMCIS 2007 Proceedings, 339.

Ellison, N. B., Steinfield, C., \& Lampe, C. (2007). The benefits of Facebook “friends": social capital and college students' use of online social network sites. Journal of Computer-Mediated Communication, 12(4), 1143-1168.

Fenton, N., \&Barassi, V. (2011). Alternative media and social networking sites: the politics of individuation and political participation. The Communication Review, 14(3), 179-196.

Fernandes, J., Giurcanu, M., Bowers, K. W., \& Neely, J. C. (2010). The writing on the wall: a content analysis of college students' Facebook groups for the 2008 Presidential Election. Mass Communication and Society, 13(5), 653-675.

Gearheart, S., Moe, A., \& Zhang, B. (2020). Hostile media bias on social media: testing the effect of user comments on perceptions of news bias and credibility. Human Behavior and Emerging Technology, 2(2), 140-148. 


\section{Macrothink}

International Journal of Linguistics

ISSN 1948-5425 2020, Vol. 12, No. 6

Goodman, S. D. (2011). Social media: the use of Facebook and twitter to impact political unrest in the Middle East through the power of collaboration. Retrieved from http://digitalcommons.calpoly.edu/joursp/25

Gunawan, S. T. E. V. E. N. (2017). Sherlock Holmes' impoliteness strategies and other characters' responses in Sherlock TV Series Season 1 episode 1. Unpublished Undergraduate Thesis. Yogyakarta: Sanata Dharma University.

Haenschen, K. (2019). Self-reported versus digitally recorded: measuring political activity on Facebook. Social Science Computer Review. Retrieved from https://journals.sage-pub.com/doi/10.1177/0894439318813586

Hammod, N. M., \& Abdul-Rassul, A. (2017). Impoliteness strategies in English and Arabic Facebook comments. International Journal of Linguistics, 9(5), 97-112.

Iskander, E. (2011). Connecting the national and the virtual: can Facebook activism remain relevant after Egypt's January 25 uprising?. International Journal of Communication, 5, $13-15$.

Jucker, A. H. (2009). Early modern English news discourse: newspapers, pamphlets and scientific news discourse (Vol. 187). John Benjamins Publishing.

Khamis, S., Gold, P. B., \& Vaughn, K. (2012). Beyond Egypt's "Facebook Revolution" and Syria's "YouTube Uprising": comparing political contexts, actors and communication strategies. Arab Media \& Society, 15 (Spring), 1-30.

Kushin, M. J., \& Kitchener, K. (2009). Getting political on social network sites: exploring online political discourse on Facebook. First Monday, 14(11). https://doi.org/10.5210/fm.v14i11.2645

Lakoff, R. (1972). Language in Context. Language, 48(4), 907-927.

Lin, H. C. (2017). How political candidates' use of Facebook relates to the election outcomes. International Journal of Market Research, 59(1), 77-96.

Mills, S. (2002). Rethinking politeness, impoliteness and gender identity (Vol. 89).

Mor, Y., Kligler-Vilenchik, N., \&Maoz, I. (2015). Political expression on Facebook in a context of conflict: dilemmas and coping strategies of Jewish-Israeli youth. Social Media Society, 1(2), 2056305115606750.

Pennington, N., Winfrey, K. L., Warner, B. R., \& Kearney, M. W. (2015). Liking Obama and Romney (on Facebook): An experimental evaluation of political engagement and efficacy during the 2012 general election. Computers in Human Behavior, 44, 279-283.

Primadianti, N. (2015). A Pragmatic analysis of impoliteness in paranorman movie. SastraInggris-Quill, 4(3), 215-222.

Robertson, S. P., Vatrapu, R. K., \& Medina, R. (2010). Off the wall political discourse: Facebook use in the 2008 US Presidential election. Information Polity, 15(1-2), 11-31. 


\section{Macrothink}

International Journal of Linguistics

ISSN 1948-5425

2020, Vol. 12, No. 6

Rosanti, I. R. (2016). Impoliteness in criticism in Vlog. Master's thesis, Universitas Muhammadiyah Surakarta.

Rouse, M. (2009). Definition Facebook. Retrieved from http://whatis.techtarget.com/definition/Facebook

Sen, S. (2018). Chennaifloods: Use of social media and collective intelligence in disasters. Contested Development Working Paper, 79, King's College London.

Shinta, V. M., Hamzah, H., \&Wahyuni, D. (2018). Impoliteness strategies used by supporters and detractors of ahok in their online comments by gender. E-Journal English Language and Literature, 7(1), 225-236.

Shofyah, N. W. (2015). The use of impoliteness strategies in easy a movie. Yogyakarta: State Islamic University Sunan Kalijaga.

Stieglitz, S., \& Dang-Xuan, L. (2012). Impact and diffusion of sentiment in political communication: An empirical analysis of public political Facebook pages. Proceedings of the 20th European Conference on Information Systems (ECIS).

Tang, G., \& Lee, F. L. (2013). Facebook use and political participation: the impact of exposure to shared political information, connections with public political actors, and network structural heterogeneity. Social Science Computer Review, 31(6), 763-773.

Theocharis, Y., \& Lowe, W. (2016). Does Facebook increase political participation? Evidence from a field experiment. Information, Communication \& Society, 19(10), 1465-1486.

Thomas, J. (1995). Meaning in interaction: an introduction to pragmatics. New York: Longman.

Valera-Ordaz, L. (2018). Political conversations on Facebook: exploring the role of homophily in argumentation and communicative interaction. Revista Latina de Communicion Social, 73, 55-73.

Vraga, E. K., Thorson, K., Kligler-Vilenchik, N., \& Gee, E. (2015). How individual sensitivities to disagreement shape youth political expression on Facebook. Computers in Human Behavior, 45, 281-289.

Williams, C., \& Gulati, G. (2008). What is a social network worth? Facebook and vote share in the 2008 Presidential Primaries. Annual Meeting of the American Political Science Association (Vol. 54, p. 21).

Zhong, W. (2018). Linguistic impoliteness strategies in Sina Weibo comments. International Journal of Linguistics, 6(2), 35-46. 


\section{Appendix}

Screenshots of Some Comments

Comment (2) from post (1)

Comment (5) from post (1):

Hosam Ahmad Al-Hayajneh

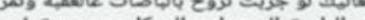

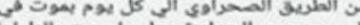

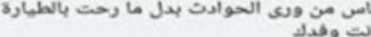

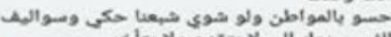

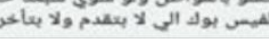$$
\text { Nisreen Alnuimi }
$$

سعدنا بمعرفة سفرك للعقبة بالطائرة بينما

المواطن العادي بيسافر ع الطريق الصحراوي.

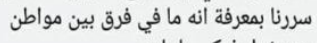
ومسؤول فيكي يا بلدي

Comment (9) from post (1):

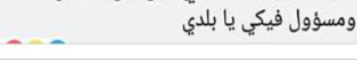

Comment (10) from post (1):

$$
\text { موسى محهد هويل العثمان }
$$

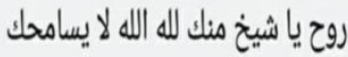

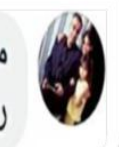

Alaa Rababah

استحي عحالك واستقيل

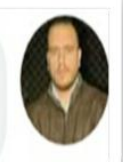

Comment (1) from post (2):

Mohmmed Waleed Alkashman

ولسه الحبل ع الجرار لا اخر السنه والسنه الي

بعدها بتزيد او رح تزيد وتزيد طول ما النهج

نفسه 
Comment (4) from post (2):

Comment (7) from post (2):

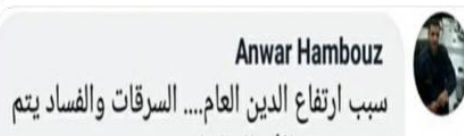

$$
\begin{aligned}
& \text { تصدير هذه الأموال للخارج }
\end{aligned}
$$

$$
\text { جاد جاء الله يكثرن }
$$

\section{Copyrights}

Copyright for this article is retained by the author(s), with first publication rights granted to the journal.

This is an open-access article distributed under the terms and conditions of the Creative Commons Attribution license (http://creativecommons.org/licenses/by/4.0/) 